\title{
Intestinal parasites of endangered orangutans (Pongo pygmaeus) in Central and East Kalimantan, Borneo, Indonesia
}

\author{
E. M. LABES ${ }^{1 *}$, D. HEGGLIN ${ }^{1}$, F. GRIMM ${ }^{1}$, W. NURCAHYO ${ }^{2}$, M. E. HARRISON ${ }^{3,4}$, \\ M. L. BASTIAN ${ }^{5}$ and P. DEPLAZES ${ }^{1}$ \\ ${ }^{1}$ University of Zurich, Institute of Parasitology, Winterthurerstrasse 266a, 8057 Zurich, Switzerland \\ ${ }^{2}$ Gadjah Mada University, Faculty of Veterinary Medicine, Laboratory of Parasitology, 55281 Yogyakarta, Indonesia \\ ${ }^{3}$ University of Cambridge, The Anatomy School, Wildlife Research Group, Downing Street, Cambridge CB2 3DY, UK \\ ${ }^{4}$ University of Palangka Raya, Centre for the International Cooperation in Management of Tropical Peatlands, Palangka \\ Raya, Central Kalimantan, Indonesia \\ ${ }^{5}$ Duke University, Department of Biological Anthropology and Anatomy, Science Drive, Box 90383, Durham, \\ NC 27708-0383, USA
}

(Received 23 May 2009; revised 4 Fuly 2009; accepted 7 Fuly 2009; first published online 21 September 2009)

\begin{abstract}
SUMMARY
Faecal samples from 163 captive and semi-captive individuals, 61 samples from wild individuals and 38 samples from captive groups of Bornean orangutans (Pongo pygmaeus) in Kalimantan, Indonesia, were collected during one rainy season (November 2005-May 2006) and screened for intestinal parasites using sodium acetate-acetic acid-formalin-concentration (SAFC), sedimentation, flotation, McMaster- and Baermann techniques. We aimed to identify factors influencing infection risk for specific intestinal parasites in wild orangutans and individuals living in captivity. Various genera of Protozoa (including Entamoeba, Endolimax, Iodamoeba, Balantidium, Giardia and Blastocystis), nematodes (such as Strongyloides, Trichuris, Ascaris, Enterobius, Trichostrongylus and hookworms) and one trematode (a dicrocoeliid) were identified. For the first time, the cestode Hymenolepis was detected in orangutans. Highest prevalences were found for Strongyloides (individuals 37\%; groups 58\%), hookworms (41\%; 58\%), Balantidium (40\%; 61\%), Entamoeba coli $(29 \% ; 53 \%)$ and a trichostrongylid $(13 \% ; 32 \%)$. In re-introduction centres, infants were at higher risk of infection with Strongyloides than adults. Infection risk for hookworms was significantly higher in wild males compared with females. In groups, the centres themselves had a significant influence on the infection risk for Balantidium. Ranging patterns of wild orangutans, overcrowding in captivity and a shift of age composition in favour of immatures seemed to be the most likely factors leading to these results.
\end{abstract}

Key words: Bornean orangutan, Pongo pygmaeus, intestinal parasite, infection risk parameter.

\section{INTRODUCTION}

Orangutans belong to the family Pongidae and represent the only great ape in Asia. Wild populations are restricted to the islands of Borneo (Pongo pygmaeus) and Sumatra (Pongo abelii), in Indonesia and Malaysia (Rijksen and Meijaard, 1999). Currently, 3 subspecies of Bornean orangutans are recognized (P. p. pygmaeus, P. p. wurmbii and P. p. morio) (Xu and Arnason, 1996; Groves, 1999). In the last few decades, the total number and distribution of orangutans have reduced drastically, primarily as a result of habitat loss (Wich et al. 2008). In 1997, the population estimate for Bornean orangutans was only $7 \%$ of that in 1900 (Rijksen and Meijaard, 1999), and the species is now classified as endangered by the

* Corresponding author: University of Zurich, Institute of Parasitology, Winterthurerstrasse 266a, 8057 Zurich, Switzerland. Tel: +41 (0)44310 3210. Fax: +41(0)44 310 3211. E-mail : elabes@bluewin.ch
International Union for Conservation of Nature (IUCN, 2008).

Infectious diseases caused by parasites can pose a severe threat to great ape survival. Parasites can be transmitted between wild and rehabilitant populations, between both of these and other wildlife species, and between great apes and humans and/or their livestock (Hira and Patel, 1980; Ashford et al. 1990 ; Landsoud-Soukate et al. 1995 ; Michaud et al. 2003; Hope et al. 2004; Appelbee et al. 2005 ; Nunn and Altizer, 2006; Garber, 2008; Pusey et al. 2008). Since orangutans share $\sim 96.4 \%$ of their genetic information with humans (see Miyamoto, 1988; Chen and Li, 2001), zoonotic diseases are of major significance. Certain viral diseases and parasite infections have already been well documented in African great apes (Eberle and Hilliard, 1989; Brooks et al. 2002; Grimm et al. 2003; Whitfield, 2003; Karesh and Reed, 2004; Graczyk et al. 1999, 2001, 2002; Sleeman et al. 2000; Freeman et al. 2004; Van Heuverswyn et al. 2006; Kaur et al. 2008; Williams 
et al. 2008). Although the occurrence of various pathogenic gastrointestinal parasites has been described in captive, rehabilitant and wild orangutans (Cummins et al. 1973; Collet et al. 1986; Leeflang and Markham, 1986; Foitová et al. 2009), the distribution and transmission of parasites of orangutans are still poorly understood compared with African great apes.

Captive orangutans are often kept under unnatural conditions and in close contact with humans and/or other animal species, which allows pathogens to be readily transmitted from humans to orangutans (Chitwood, 1970; Ott-Joslin, 1993) and vice versa. Intestinal parasites that have already been described in orangutans (Rijksen, 1978; Collet et al. 1986; Wells et al. 1990; Djojosudharmo and Gibson, 1993 ; Warren, 2001; Kilbourn et al. 2003; Mul et al. 2007; Foitová et al. 2009) have also been identified in humans in Indonesia (Cross et al. 1975, 1976; Putrali et al. 1977; Joseph et al. 1978) and include various genera of Protozoa (Entamoeba, Endolimax, Iodamoeba, Balantidium and Giardia), nematodes (Strongyloides, Ascaris, Enterobius, Trichuris and hookworms), cestodes (Hymenolepis) and trematodes (dicrocoeliids). However, only few studies of orangutan health have been published in recent years (Warren, 2001; Kilbourn et al. 2003 ; Mul et al. 2007; Foitová et al. 2009), and most studies include only small numbers of free-ranging orangutans (see Rijksen, 1978; Collet et al. 1986; Djojosudharmo and Gibson, 1993; Warren, 2001; Mul et al. 2007), probably due to the difficulty of acquiring faecal samples from wild individuals. Furthermore, although transmission pathways of parasitic infections should differ between wild and captive populations, factors influencing the infection risk for specific parasites in wild populations compared with those living in captivity have not yet been elucidated.

Conservation efforts that focus on the health management of wild and captive orangutan populations should not only consider parasite prevalence, but also identify parameters that may increase infection risk and the anthropogenic influence on pathogen infections. Therefore, data from larger groups of wild individuals are needed, particularly since orangutans differ profoundly in their biology from African great apes (e.g., Knott, 2001, 2005; Yamagiwa, 2004).

In this study, wild Bornean orangutans from 3 distinct populations were compared with captive individuals and groups from 2 re-introduction centres. All sites were located in Kalimantan, Borneo. Differences in parasite prevalence were investigated with respect to ecological and behavioural factors as well as husbandry. The aim of the study was to identify factors that significantly influence the infection risk of individuals for specific parasites under different conditions. Gaining information in this context would provide a first step in understanding whether similar underlying factors influence infection risk in wild and captive orangutan populations, or whether these factors differ.

\section{MATERIALS AND METHODS}

\section{Study site}

Samples were collected at 2 re-introduction centres, both of which are managed by the Borneo Orangutan Survival Foundation (BOS), Indonesia. The Nyaru Menteng Orangutan Re-introduction Centre (centre 1) was founded in 1998 and is located $28 \mathrm{~km}$ north of Palangka Raya $\left(2^{\circ} 21^{\prime} 56 \cdot 27^{\prime \prime} \mathrm{S}, 113^{\circ} 55^{\prime} 12 \cdot 48^{\prime \prime} \mathrm{E}\right)$, the capital of the province of Central Kalimantan. The centre covers 1.5 ha and neighbours the Nyaru Menteng Arboretum, a 62.5 ha lowland swamp forest. The Wanariset Orangutan Reintroduction Centre (centre 2) was founded in 1991 and is located $35 \mathrm{~km}$ north of Balikpapan $\left(1^{\circ} 16^{\prime} 01 \cdot 03^{\prime \prime} \mathrm{S}, 116^{\circ}\right.$ $\left.50^{\prime} 01 \cdot 46^{\prime \prime} \mathrm{E}\right)$, East Kalimantan. Centre 1 is regularly accessed by long-tailed macaques (Macaca fascicularis) and domestic dogs roaming for food. Domestic cats from the neighbourhood are often seen at both centres. Both centres occasionally receive other wild animals through confiscations, including Mueller's gibbons (Hylobates muelleri muelleri), proboscis monkeys (Nasalis larvatus), Bornean slow lorises (Nycticebus menagensis) and sun bears (Helarctos malayanus).

Faecal samples from free-ranging (wild) orangutans were collected from 3 geographically isolated populations at the Tuanan Research Station (site 1) in the Mawas area $\left(2^{\circ} 09^{\prime} 06 \cdot 1^{\prime \prime} \mathrm{S}, 114^{\circ}\right.$ $26^{\prime} 26 \cdot 3^{\prime \prime} \mathrm{E}$ ), the Sungai Lading Research Station (site 2 ), separated from the Mawas area by artificial water channels, and the Natural Laboratory of Peat Swamp Forest, Sabangau $\left(2^{\circ} 19^{\prime} 40 \cdot 72^{\prime \prime} \mathrm{S}, 113^{\circ} 54^{\prime} 39 \cdot 74^{\prime \prime} \mathrm{E}\right)$ (site 3 ), a protected research area $20 \mathrm{~km}$ southwest of Palangka Raya. Orangutan density ranged from $4 \cdot 25$ to $4 \cdot 5$ individuals $/ \mathrm{km}^{2}$ in Tuanan (Van Schaik et al. 2005), $2 \cdot 3$ individuals $/ \mathrm{km}^{2}$ in Sabangau (Ley-Vela, 2005) and $7 \cdot 74$ individuals $/ \mathrm{km}^{2}$ at Sungai Lading (Bastian, 2008). All field sites are located in the province of Central Kalimantan and consist of disturbed peat-swamp forest habitat that had previously been subject to selective commercial and informal logging.

\section{Subjects}

Investigations at centre 1 were carried out between November 2005 and January 2006, during which time a total of 404 orangutans lived at the centre. Sample collection and analysis at centre 2 was carried out between March and May 2006, when the centre took care of a total of 191 orangutans. Individuals were either captive (confiscated) or semi-captive 
Table 1. Number of investigated samples with respect to sex, age classes and group size

\begin{tabular}{|c|c|c|c|}
\hline Sample $(n)$ & Variable & Category & $\mathrm{N}(\%)$ \\
\hline $\begin{array}{l}\text { Individuals in re-introduction centres } \\
(n=163 \text { samples })\end{array}$ & $\begin{array}{l}\text { Sex } \\
\text { Age group }\end{array}$ & $\begin{array}{l}\text { Females } \\
\text { Males } \\
\text { Infants } \leqslant 5 \text { years } \\
\text { Subadults } 6-8 \text { years } \\
\text { Adults }>8 \text { years }\end{array}$ & $\begin{array}{l}77(47) \\
86(53) \\
69(42) \\
30(18) \\
61(37)\end{array}$ \\
\hline $\begin{array}{l}\text { Individuals in field sites } \\
(n=61 \text { samples })\end{array}$ & $\begin{array}{l}\text { Sex } \\
\text { Age group }\end{array}$ & $\begin{array}{l}\text { Females } \\
\text { Males } \\
\text { Infants/Adolescents } \leqslant 7-9 \text { years } \\
\text { Subadults } 10-14 \text { years } \\
\text { adults } \geqslant 15 \text { years }\end{array}$ & $\begin{aligned} 24 & (39) \\
37 & (61) \\
7 & (11) \\
4 & (7) \\
50 & (82)\end{aligned}$ \\
\hline $\begin{array}{l}\text { Groups in re-introduction centres } \\
(n=38 \text { samples })\end{array}$ & $\begin{array}{l}\text { Sex } \\
\text { Group size }\end{array}$ & $\begin{array}{l}\text { Only females } \\
\text { Only males } \\
\text { Mixed sexes } \\
2 \text { Individuals } \\
>2 \text { Individuals* }\end{array}$ & $\begin{aligned} 10 & (26) \\
8 & (21) \\
20 & (53) \\
17 & (45) \\
21 & (55)\end{aligned}$ \\
\hline
\end{tabular}

* 3-24 individuals per group.

(wild-caught individuals, living in degraded forest fragments that had entered oil-palm or other plantations, from which they were rescued) and kept under the same husbandry conditions. Because of their different geographical locations, centre 1 had more orangutans of the subspecies $P$. p. wurmbii, whereas centre 2 had more $P$. p. morio. Both centres applied the same programme of rehabilitation, aiming to release the apes into protected forest habitat. The field sites were inhabited by 3 distinct populations of P. p. wurmbii. Samples from habituated individuals in field sites were collected over one wet season between November 2005 and April 2006.

\section{Sample collection}

A total of 567 faecal samples were collected from orangutans at both the re-introduction centres and the field sites. Between 1 and 4, or 1 and 9 samples, respectively, were collected per individual and group. The number of samples per individual and group depended on different factors; e.g., housing system and social rehabilitation programme in captive and semi-captive orangutans, and monitoring restrictions in wild individuals. To guarantee the same sensitivity for each subgroup of the multivariate analyses, we included only the first sample of each individual $(n=224)$ and group $(n=61)$. Therefore, all prevalences recorded herein must be considered as minimal prevalence rates.

The age of the individuals was estimated by experienced staff at the re-introduction centres and biologists at the field sites, respectively. However, young orangutans, in particular, develop at a different rate in re-introduction centres compared with those in the wild. Following Rijksen (1978), and in order to avoid incorrect age classifications, individuals in the re-introduction centres and in the field sites were divided into different age groups (Table 1). The age of 3 individuals was unknown (2\%). Thirtyeight faecal samples from orangutans kept in groups (21 and 17 in centres 1 and 2) were collected as blind samples and analysed for intestinal parasites. These groups did not include orangutans that had been investigated individually.

\section{Sample analysis}

The cages in the centres were installed between 20 and $80 \mathrm{~cm}$ above the ground. Thus, faeces dropped down between the cage bars, and samples were collected from the ground before the cages were cleaned early in the morning. At the field sites, samples were collected immediately after defaecation. All samples were homogenized thoroughly and examined using different coproscopic techniques to ensure the detection of all parasite stages potentially present in the samples. For the detection of protozoa, the sodium acetate-acetic acid-formalin-concentration (SAFC) technique was applied using $1 \mathrm{~g}$ of each sample (Marti and Escher, 1990). Ziehl-Neelsen staining of a faecal smear was used additionally to identify Cryptosporidium spp. (Current, 1989). The Baermann-technique (Garcia and Bruckner, 1997; $10 \mathrm{~g})$ and a combined sedimentation and flotation (Garcia and Bruckner, 1997) were used to detect helminth larvae and eggs $(10 \mathrm{~g})$. Egg counts were performed by a modified McMaster technique (Schmidt, 1971; 4 g). Parasites were identified microscopically on the basis of the morphological characteristics (size, shape, colour and contents) of eggs, cysts and larvae. An ocular micrometer was used to measure the sizes of parasite eggs, cysts and larvae. Identification was mainly made to the genus level, because specific identification was usually not possible. 


\section{Statistical analysis}

To identify specific factors affecting infection risk of orangutans, multivariate logistic regression modelling was applied, which avoids the pitfalls of univariate analyses. For modelling of the prevalence of identified intestinal parasites in individuals, only parasites with an overall prevalence of $\geqslant 10 \%$ were included in the analysis. The variables 'origin', 'age' and 'sex' were selected as the most promising, independent variables for the modelling procedure of each the reintroduction centres and the field sites. Although the majority of orangutans at centres 1 and 2 were either $P$. p. wurmbii or $P$. p. morio, respectively, it was not possible to classify each individual to the subspecies level with certainty, because of the possibility of hybrids. For this reason, the variable 'origin' primarily includes the geographical location of centres 1 and 2, but also considers the corresponding subspecies.

In order to distinguish infections that were most probably present before entry into the centre and those acquired after arrival, a distinction was made between orangutans depending on how long they had been at the centre before the first sample was collected (new arrivals within 1 week before sampling: $n=33$ [20\%]; arrivals 8-21 days before sampling: $n=31 \quad[19 \%]$; and arrivals $>21$ days before sampling: $n=132$ [81\%], respectively. In addition, the variables 'group contact' (with or without tactile contact to neighbouring conspecifics) and 'captive status' (captive vs. semi-captive) were included for the reintroduction centres. For the field sites, the variable 'flanged' versus 'unflanged males' was included because the development of cheek pads is considered a dominance sign in adult male orangutans (Utami et al. 2002). Differences in hormonal profiles (flanged males have higher concentrations of testosterone) and specific costs incurred (higher energetic demands due to increased size and injuries from fights) may also lead to decreased immuno-competence in flanged males (Maggioncalda et al. 1999) and, thus might relate to their susceptibility to parasitic infections. This variable was not considered for captive male orangutans, because its effect in situations in which individuals are caged is difficult to measure and the sample size in the study was too small. Finally, the variable 'mother' versus 'non-mother' was considered for females. For the groups, only the variables 'origin', 'captive status', 'group contact' and 'group size' were included in the analysis. The variable 'group size' included the absolute number of individuals per group.

Logistic regression models were calculated for each selected parasite individually. Models were fitted using all possible combinations of the selected predictor variables, but only models that significantly explained variation in the data set (log-likelihood ratio test) were considered for the model-selection process. Best models were selected using Akaike's information criterion (AIC, Akaike, 1973; Burnham and Anderson, 1998) corrected for small sample sizes (AICc). The model with the lowest AICc was considered the most parsimonious and only models with $\triangle \mathrm{AICc}<2$ compared to the model with the lowest AICc were selected. Akaike model weights were calculated (Burnham and Anderson, 1998) to determine the degree to which a model was supported by the data. By definition, weights of selected models sum to 1 , and higher weights indicate better explanatory power. To evaluate the relative importance of each explanatory variable, the AICc weights were summed over all models where that variable was present. A variable sums to 1 when it is included in all selected models, whereas a variable present in just one model is assigned the value of the corresponding model. The variables were then ranked according to the resulting AICc weight sums. Finally, effect sizes of parameters of the selected models were calculated using model averaging: parameter estimates are multiplied by the weight of the particular model and summed over all selected models containing the particular parameter to give the weighted average of parameter estimates (Johnson and Omland, 2004). Standard errors were calculated for parameter estimates following Burnham and Anderson (1998). Parameter estimate and $1.96 *$ standard errors were exponentially transformed to express odds ratios and their $95 \%$ confidence intervals. An event is equally likely in both groups when the odds ratio is 1 . Odds ratios with $95 \%$-CI's that include 1 were not interpreted. Statistical analyses were performed using SPSS 13.0 (Norusis, 1986). The fit of the logistic regression models were tested by likelihood ratio tests. Maximal $P$ values for the likelihood ratio tests are given for the selected models.

\section{RESULTS}

A total of 163 faecal samples from the 2 reintroduction centres (centre 1; 118 samples, centre $2 ; 45$ samples) and 61 wild individuals (sites $1-3 ; 34$, 14 samples and 13, respectively) were examined. Cysts and trophozoites of 6 genera of Protozoa, as well as eggs and larvae of various nematodes were identified (Table 2). In individuals, 3 genera of Protozoa, as well as Strongyloides sp., hookworms and a trichostrongylid nematode had prevalence rates of $\geqslant 10 \%$. Subsequently, parasites whose prevalence was $\geqslant 10 \%$ were included in the modelling procedure. Eggs from hookworms measured $62 \cdot 0 \pm 2 \cdot 0 \times 37 \cdot 7 \pm 2.5 \mu \mathrm{m}$ and were not identified to genus-level. Other strongylid eggs, measuring $74 \cdot 4 \pm 3.6 \times 45 \cdot 8 \pm 4 \cdot 0 \mu \mathrm{m}$ in size, tapered at one end, thin-shelled and colourless, were consistent with Trichostrongylus (and thus termed 
Table 2. Prevalence of parasites identified in faecal samples from individuals at re-introduction centres and field sites

\begin{tabular}{|c|c|c|c|c|c|c|c|c|}
\hline & $\begin{array}{l}\text { Captive } \\
(n=119 \\
\text { samples }) \\
(\%)\end{array}$ & $95 \% \mathrm{Cl}$ & $\begin{array}{l}\text { Semi- } \\
\text { captive } \\
(n=44 \\
\text { samples }) \\
(\%)\end{array}$ & $95 \% \mathrm{Cl}$ & $\begin{array}{l}\text { Total } \\
\text { centres } \\
(n=163 \\
\text { samples }) \\
(\%)\end{array}$ & $95 \% \mathrm{Cl}$ & $\begin{array}{l}\text { Sites } \\
(n=61 \\
\text { samples }) \\
(\%)\end{array}$ & $95 \% \mathrm{Cl}$ \\
\hline \multicolumn{9}{|c|}{ NON-PATHOGENIC PROTOZOA } \\
\hline Blastocystis sp. & 15 & $9 \cdot 2-22 \cdot 8$ & 14 & $5 \cdot 1-27 \cdot 4$ & 15 & $9 \cdot 7-21 \cdot 1$ & 11 & $4 \cdot 7-22 \cdot 2$ \\
\hline Entamoeba coli & 22 & $14 \cdot 8-30 \cdot 4$ & 32 & $18 \cdot 6-47 \cdot 6$ & 25 & $18 \cdot 1-31 \cdot 9$ & 43 & $30 \cdot 0-55 \cdot 9$ \\
\hline Entamoeba hartmanni & 6 & $2 \cdot 4-11 \cdot 7$ & 9 & $2 \cdot 5-21 \cdot 7$ & 7 & $3 \cdot 4-11 \cdot 8$ & 15 & $7 \cdot 0-26 \cdot 2$ \\
\hline Endolimax nana & 9 & $4 \cdot 7-15 \cdot 9$ & 7 & $1 \cdot 4-18 \cdot 7$ & 9 & $4 \cdot 8-14 \cdot 0$ & 3 & $0 \cdot 4-11 \cdot 3$ \\
\hline Iodamoeba buetschlii & 4 & $1 \cdot 4-9 \cdot 5$ & 7 & $1 \cdot 4-18 \cdot 7$ & 5 & $2 \cdot 1-9 \cdot 4$ & 2 & $0 \cdot 0-8 \cdot 8$ \\
\hline \multicolumn{9}{|c|}{ FACULTATIVELY PATHOGENIC PROTOZOA } \\
\hline Balantidium sp. & 39 & $29 \cdot 9-48 \cdot 0$ & 41 & $28 \cdot 3-59$ & 40 & $32 \cdot 3-47 \cdot 8$ & 41 & $28 \cdot 6-54 \cdot 3$ \\
\hline \multicolumn{9}{|c|}{ POTENTIALLY PATHOGENIC PROTOZOA } \\
\hline $\begin{array}{l}\text { Entamoeba histolytica/ } \\
\text { E. dispar }\end{array}$ & 3 & $0 \cdot 9-8 \cdot 4$ & 35 & $0 \cdot 1-12$ & 3 & $1 \cdot 0-7 \cdot 0$ & 28 & $17 \cdot 1-40 \cdot 8$ \\
\hline Entamoeba spp. & 12 & $6 \cdot 6-19$ & 6 & $8 \cdot 2-32 \cdot 7$ & 13 & $8 \cdot 7-19 \cdot 7$ & 16 & $8 \cdot 2-28 \cdot 1$ \\
\hline Giardia sp. & 3 & $0 \cdot 9-8 \cdot 4$ & 0 & $0 \cdot 6-15 \cdot 5$ & 4 & $1 \cdot 4-7 \cdot 8$ & 3 & $0 \cdot 4-11 \cdot 3$ \\
\hline \multicolumn{9}{|l|}{ HELMINTHS } \\
\hline Strongyloides sp. & 39 & $30 \cdot 7-48 \cdot 9$ & 34 & $20 \cdot 5-49 \cdot 9$ & 38 & $30 \cdot 6-46 \cdot 0$ & 33 & $21 \cdot 3-46 \cdot 0$ \\
\hline Hookworm & 31 & $22 \cdot 9-40 \cdot 2$ & 43 & $28 \cdot 3-59$ & 34 & $27 \cdot 1-42 \cdot 2$ & 59 & $45 \cdot 7-71 \cdot 4$ \\
\hline $\begin{array}{l}\text { 'Trichostrongylus-like' } \\
\text { nematodes }\end{array}$ & 3 & $0 \cdot 9-8 \cdot 4$ & 25 & $13 \cdot 2-40 \cdot 3$ & 9 & $5 \cdot 2-14 \cdot 7$ & 21 & $11 \cdot 9-33 \cdot 7$ \\
\hline Trichuris sp. & 7 & $2 \cdot 9-12 \cdot 8$ & 14 & $5 \cdot 2-27 \cdot 4$ & 9 & $4 \cdot 8-14 \cdot 0$ & 7 & $1 \cdot 8-15 \cdot 9$ \\
\hline Ascaris sp. & 1 & $0-4 \cdot 6$ & 0 & $0-8$ & 1 & $0 \cdot 0-3 \cdot 4$ & 0 & $0 \cdot 0-5 \cdot 9$ \\
\hline Enterobius sp. & 1 & $0-4 \cdot 6$ & 2 & $0 \cdot 1-12$ & 1 & $0 \cdot 1-4 \cdot 4$ & 15 & $7 \cdot 0-26 \cdot 2$ \\
\hline Dicrocoelium sp. & 0 & $0-3 \cdot 1$ & 0 & $0-8$ & 0 & $0 \cdot 0-2 \cdot 2$ & 0 & $0 \cdot 0-5 \cdot 9$ \\
\hline Hymenolepis sp. & 0 & $0-3 \cdot 1$ & 0 & $0-8$ & 0 & $0 \cdot 0-2 \cdot 2$ & 3 & $0 \cdot 4-11 \cdot 3$ \\
\hline
\end{tabular}

"Trichostrongylus-like"). The germinal mass did not fill the shell of the eggs.

The samples of 5 individuals contained Dicrocoelium-like eggs. The eggs were $43 \pm 2 \cdot 4 \times 27 \cdot 8 \pm$ $2 \cdot 1 \mu \mathrm{m}$ in size and had a thick, brown shell, possessing an inconspicuous operculum and a miracidium. The individuals included 3 female and 1 male semicaptive orangutans at centre 1 and 1 captive male at centre 2. Two males and 1 female infant at the Tuanan Research Station tested positive for Hymenolepis. Eggs were $66 \pm 6 \cdot 3 \mu \mathrm{m}$ in diameter, subspherical, with a firm egg shell and a brown-coloured hue. The eggs lacked polar filaments and contained a hexacanth embryo.

Overall prevalence of intestinal parasites in samples from orangutans housed in groups was much higher than in those housed individually (Table 3 ). The range of identified parasites did not generally differ between groups and individuals. E. coli, E. histolytica/dispar, Balantidium sp., Strongyloides sp., hookworms and Trichostrongylus-like nematodes had significantly higher prevalences in samples collected from orangutans kept in groups than in individually-housed orangutans and were subsequently selected for the statistical analysis. Only 33 (20.3\%) samples from individuals at the centres, the sample from 1 group $(2 \cdot 6 \%)$ and $6(9 \cdot 8 \%)$ samples from wild orangutans tested negative for parasites. All other samples tested positive for between 1 and 9 intestinal parasite species.

Except for 6 samples, all collected at centre 1, the number of helminth eggs identified in individuals was always <50 eggs/g (epg) faeces. Higher egg counts were recorded for 2 males $\leqslant 5$ years of age with tactile contact to conspecifics (Trichuris sp.: 300 epg, Strongyloides sp.: $50 \mathrm{epg}$ ), 1 female of the same age group but without tactile contact (Strongyloides sp.: 10700 epg, hookworms : 13350 epg, Trichostrongylus-like nematodes: 400 epg, Trichuris sp. : $150 \mathrm{epg}$ ) and one 6 to 8 -year-old male without tactile contact (Strongyloides sp. : $1100 \mathrm{epg}$ ). The samples of two $>8$-year-old males without tactile contact to conspecifics had higher egg counts for 3 (Strongyloides sp.: 50 epg, hookworms: $600 \mathrm{epg}$, Trichostrongylus-like nematodes: $650 \mathrm{epg}$ ) and 2 helminths (Strongyloides sp.: $750 \mathrm{epg}$, hookworms: $250 \mathrm{epg}$ ), respectively. All samples from groups contained $<50$ epg with the exception of 1 sample with 1050 epg for Strongyloides sp. and 500 epg for hookworms, and 1 sample with 100 epg for Trichuris sp., both from centre 1 .

The model selection procedure revealed significant models for several parasites (individuals in reintroduction centres: Balantidium sp., Strongyloides sp., hookworm; groups in re-introduction centres: Balantidium sp., hookworm, Trichostrongylus-like 
Table 3. Prevalence of parasites identified in faecal samples from groups at re-introduction centres

\begin{tabular}{|c|c|c|c|c|c|c|}
\hline & $\begin{array}{l}\text { Centre } 1 \\
(n=21 \\
\text { samples }) \\
(\%)\end{array}$ & $95 \% \mathrm{Cl}$ & $\begin{array}{l}\text { Centre } 2 \\
(n=17 \\
\text { samples }) \\
(\%)\end{array}$ & $95 \% \mathrm{Cl}$ & $\begin{array}{l}\text { Total } \\
\text { centres } \\
(n=38 \\
\text { samples }) \\
(\%)\end{array}$ & $95 \% \mathrm{Cl}$ \\
\hline \multicolumn{7}{|l|}{ NON-PATHOGENIC PROTOZOA } \\
\hline Blastocystis sp. & 14 & $3 \cdot 0-36 \cdot 3$ & 12 & $1 \cdot 5-36 \cdot 4$ & 13 & $4 \cdot 4-28 \cdot 1 \%$ \\
\hline Entamoeba coli & 52 & $29 \cdot 8-74 \cdot 3$ & 53 & $27 \cdot 8-77 \cdot 0$ & 53 & $35 \cdot 8-69 \cdot 0$ \\
\hline Entamoeba hartmanni & 10 & $1 \cdot 2-30 \cdot 4$ & 18 & $3 \cdot 8-43 \cdot 4$ & 13 & $4 \cdot 4-28 \cdot 1$ \\
\hline Endolimax nana & 10 & $1 \cdot 2-30 \cdot 4$ & 24 & $6 \cdot 8-49 \cdot 9$ & 16 & $6 \cdot 0-31 \cdot 3$ \\
\hline Iodamoeba buetschlii & 5 & $0 \cdot 1-23 \cdot 8$ & 18 & $3 \cdot 8-43 \cdot 4$ & 11 & $2 \cdot 9-24 \cdot 8$ \\
\hline \multicolumn{7}{|c|}{ FACULTATIVELY PATHOGENIC PROTOZOA } \\
\hline Balantidium sp. & 76 & $52 \cdot 8-91 \cdot 8$ & 41 & $18 \cdot 4-67 \cdot 1$ & 61 & $43 \cdot 4-76 \cdot 0$ \\
\hline \multicolumn{7}{|c|}{ POTENTIALLY PATHOGENIC PROTOZOA } \\
\hline Entamoeba histolytica/E. dispar & 43 & $21 \cdot 8-66 \cdot 0$ & 35 & $14 \cdot 2-61 \cdot 7$ & 39 & $24 \cdot 0-56 \cdot 6$ \\
\hline Entamoeba spp. & 14 & $3 \cdot 0-36 \cdot 3$ & 6 & $0 \cdot 1-28 \cdot 7$ & 11 & $2 \cdot 9-24 \cdot 8$ \\
\hline Giardia sp. & 0 & $0 \cdot 0-16 \cdot 1$ & 0 & $0 \cdot 0-19 \cdot 5$ & 0 & $0 \cdot 0-9 \cdot 3$ \\
\hline \multicolumn{7}{|l|}{ HELMINTHS } \\
\hline Strongyloides sp. & 62 & $38 \cdot 4-81 \cdot 9$ & 53 & $27 \cdot 8-77 \cdot 0$ & 58 & $40 \cdot 8-73 \cdot 7$ \\
\hline Hookworm & 76 & $52 \cdot 8-91 \cdot 8$ & 35 & $14 \cdot 2-61 \cdot 7$ & 58 & $40 \cdot 8-73 \cdot 7$ \\
\hline 'Trichostrongylus-like' nematodes & 52 & $29 \cdot 8-74 \cdot 3$ & 6 & $0 \cdot 1-28 \cdot 7$ & 32 & $17 \cdot 5-48 \cdot 7$ \\
\hline Trichuris sp. & 19 & $5 \cdot 4-41 \cdot 9$ & 0 & $0 \cdot 0-19 \cdot 5$ & 11 & $2 \cdot 9-24 \cdot 8$ \\
\hline Ascaris sp. & 0 & $0 \cdot 0-16 \cdot 1$ & 0 & $0 \cdot 0-19 \cdot 5$ & 0 & $0 \cdot 0-9 \cdot 3$ \\
\hline Enterobius sp. & 0 & $0 \cdot 0-16 \cdot 1$ & 0 & $0 \cdot 0-19 \cdot 5$ & 0 & $0 \cdot 0-9 \cdot 3$ \\
\hline Dicrocoelium sp. & 0 & $0 \cdot 0-16 \cdot 1$ & 0 & $0 \cdot 0-19 \cdot 5$ & 0 & $0 \cdot 0-9 \cdot 3$ \\
\hline Hymenolepis sp. & 0 & $0 \cdot 0-16 \cdot 1$ & 0 & $0 \cdot 0-19 \cdot 5$ & 0 & $0 \cdot 0-9 \cdot 3$ \\
\hline
\end{tabular}

nematodes; wild individuals : Entamoeba spp., hookworm). For these parasites, several models with similar explanatory power were selected $(\triangle \mathrm{AICc}<2$; Tables 4 and 5).

The averaged models comprised all factors that were added to the model-selection procedure. With 2 exceptions, the $95 \%$ CI for all odds ratios included 1 and were therefore not discussed. In individuals, only age for Strongyloides sp. at the centres and gender for hookworms at the field sites were found to be significant (Tables 6 and 7). Total prevalence for individuals $\leqslant 5$ years was $53 \cdot 6 \%(95 \%$ CI $41 \cdot 2-65 \cdot 7)$, $6-8$ years $26 \cdot 7 \%(95 \%$ CI $12 \cdot 3-45 \cdot 9)$ and $>8$ years $27 \cdot 9 \%(95 \%$ CI $17 \cdot 1-40 \cdot 8)$. Wild males had an overall prevalence of $73 \%$ (95\% CI 55.9-86.2) and females of $38 \%(95 \%$ CI $18 \cdot 8-59 \cdot 4)$. There was no significant difference between the 3 field sites. In groups, only 'origin' for Balantidium sp. yielded a significant result in that the infection risk was higher in centre 1 than in centre 2 (Table 6).

\section{DISCUSSION}

Our analysis yielded 3 significant results, 1 for the field sites and 2 for the re-introduction centres. For the field sites, the ranking of the variables according to the AICc weight sums resulted in a significantly higher infection risk for hookworms in wild males than in females. No significant difference was found between flanged and unflanged males, indicating that the rank status does not influence infection risk in Bornean males. In humans, hookworms include Ancylostoma duodenale and Necator americanus, which produce eggs that cannot be distinguished morphologically (Muller, 2002). Hookworms are geohelminths, transmitted through oral, percutaneous and/or transmammary pathways. Mul et al. (2007) found a significantly higher total prevalence for intestinal parasites in wild females than in males, and interpreted this to be a result of females and their offspring having more frequent physical contact with conspecifics, compared with males. The percentage of wild individuals infected with Strongyloides, another soil transmitted nematode, was $33 \%$ in this study and $47 \%$ in the study by Mul et al. (2007). Parameters such as the level of arboreality or terrestriality influence parasite occurrence and prevalence in wild animal populations (Loehle, 1995; Vitone et al. 2004). Male Bornean orangutans are less territorial than females and frequently forage and travel over long distances on the ground, whereas this behaviour is rare for Sumatran orangutans (Delgado and Van Schaik, 2000). Male home ranges are also much larger than those of females (Singleton and Van Schaik, 2001; Setia et al. 2009), probably 3-5 times the size of female ranges, which are estimated to vary between 250 and 600 ha for P. p. wurmbii (see Utami Atmoko et al. 2009a). As a result, males will come into contact with both a greater number and more distant individuals than females. Therefore, males have more occasions for direct contact with soil and faeces from other orangutans, animal species and 
Table 4. Results from logistic-regression model selection to explain prevalence rates of Balantidium sp., Strongyloides sp. and hookworm in Bornean orangutans at re-introduction centres (individuals: $n=163$; groups : $n=38$ )

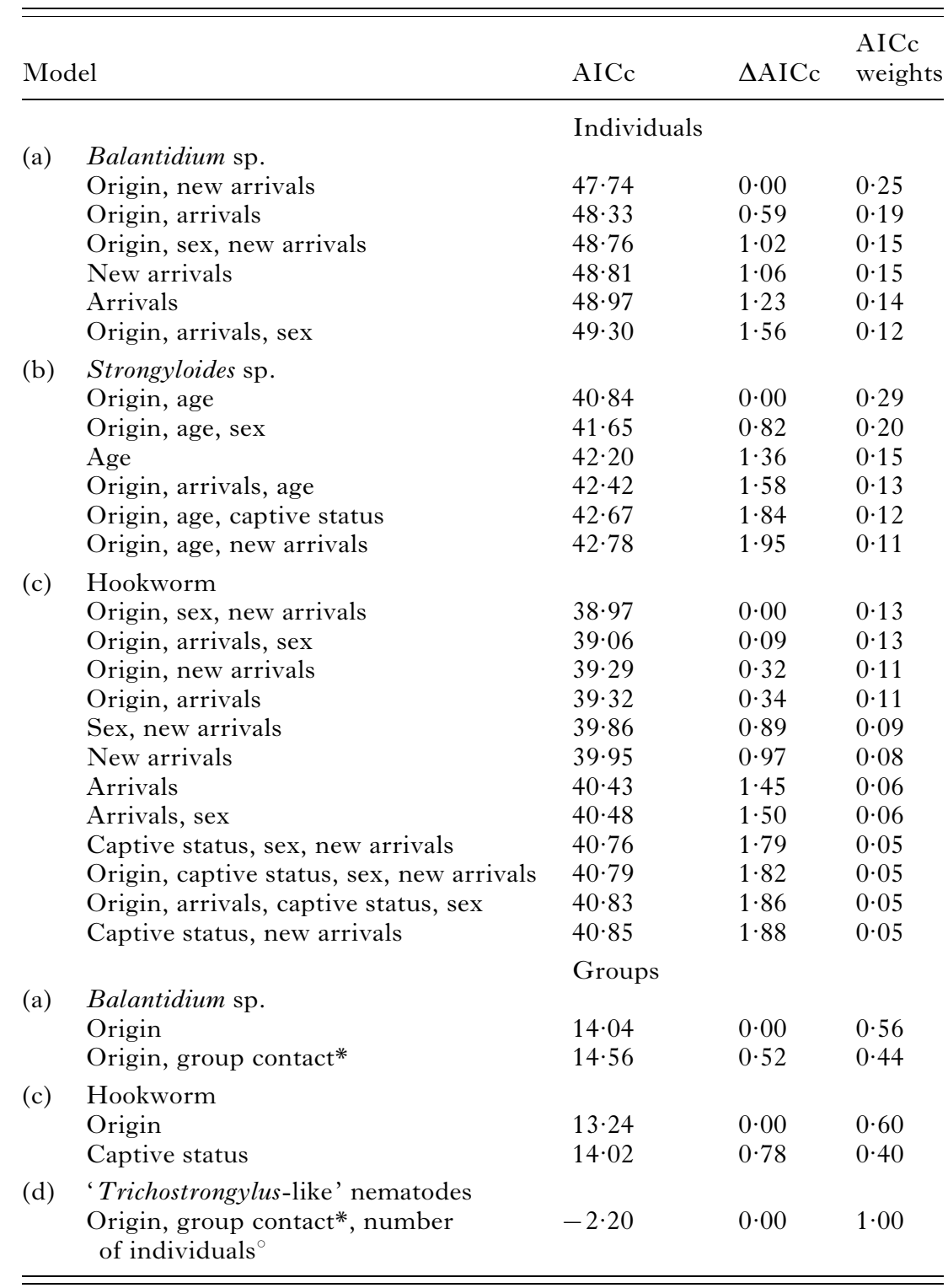

* Group contact $=$ without tactile contact $v s$ with tactile contact.

$\circ$ Number of individuals $=$ number of individuals per group.

Table 5. Results from logistic-regression model selection to explain prevalence rates of Entamoeba spp. and hookworm in Bornean orangutans at field sites $(n=61)$

\begin{tabular}{lllll}
\hline \hline Model & & AICc & $\Delta$ AICc & $\begin{array}{l}\text { AICc } \\
\text { weights }\end{array}$ \\
\hline (a) & Entamoeba spp. & & & \\
& Age, flanged & $-5 \cdot 15$ & 0.00 & 0.64 \\
& Age & $-4 \cdot 01$ & 0.57 & $0 \cdot 36$ \\
(b) & Hookworm & & & \\
& Sex & $20 \cdot 46$ & $0 \cdot 00$ & $0 \cdot 67$ \\
& Origin, sex & 21.87 & 1.41 & 0.33 \\
\hline \hline
\end{tabular}

humans, and may play an important role in the transmission of pathogens to other orangutans (and wildlife species) over large areas. For soil-transmitted nematodes, these males may be suitable distributors. Since Bornean males have more contact with females than male competitors (Van Schaik, 1999), infections are probably most frequently passed from males to these females and subsequently to their infants. Dominant males and receptive females can travel together for days or even up to months (Utami Atmoko et al. 2009b). Sumatran orangutans almost never leave the trees, probably because of terrestrial predators in their habitat (Delgado and Van Schaik, 2000; Van Schaik, 1999), but form larger temporary 
Table 6. Odds ratios (OR) and 95\% confidence intervals (CI) for the averaged models for individuals and groups at re-introduction centres

\begin{tabular}{|c|c|c|}
\hline Model & OR & $95 \% \mathrm{CI}$ \\
\hline & \multicolumn{2}{|l|}{ Individuals } \\
\hline (a) Balantidium sp. & & \\
\hline Arrivals & $0 \cdot 56$ & $0 \cdot 14-2 \cdot 27$ \\
\hline New arrivals & $2 \cdot 24$ & $0 \cdot 45-11 \cdot 12$ \\
\hline Origin (centre 1 vs centre 2) & 1.69 & $0 \cdot 68-4 \cdot 2$ \\
\hline Sex & $0 \cdot 9$ & $0 \cdot 61-1 \cdot 32$ \\
\hline \multicolumn{3}{|l|}{ (b) Strongyloides sp. } \\
\hline Origin & $2 \cdot 11$ & $0 \cdot 79-5 \cdot 69$ \\
\hline Age $(\leqslant 5$ yrs $v s>8$ yrs $)$ & $3 \cdot 05$ & $1 \cdot 39-6 \cdot 73$ \\
\hline Age $(\leqslant 8$ yrs $v s>8$ yrs $)$ & $1 \cdot 21$ & $0 \cdot 43-3 \cdot 37$ \\
\hline Captive status & $1 \cdot 03$ & $0 \cdot 87-1 \cdot 23$ \\
\hline New arrivals & 0.97 & $0 \cdot 83-1 \cdot 14$ \\
\hline Sex & $1 \cdot 1$ & $0 \cdot 79-1 \cdot 52$ \\
\hline Arrivals & $1 \cdot 1$ & $0 \cdot 83-1 \cdot 33$ \\
\hline \multicolumn{3}{|l|}{ (c) Hookworm } \\
\hline Origin & $1 \cdot 61$ & $0 \cdot 59-4 \cdot 39$ \\
\hline Sex & $0 \cdot 72$ & $0 \cdot 34-1 \cdot 53$ \\
\hline New arrivals & 0.53 & $0 \cdot 15-1 \cdot 84$ \\
\hline Arrivals & $1 \cdot 53$ & $0 \cdot 52-4 \cdot 5$ \\
\hline \multirow[t]{2}{*}{ Captive status } & $0 \cdot 93$ & $0 \cdot 67-1 \cdot 28$ \\
\hline & Groups & \\
\hline \multicolumn{3}{|l|}{ (a) Balantidium sp. } \\
\hline Origin (centre $1 v s$ centre 2$)$ & $5 \cdot 81$ & $1 \cdot 14-29 \cdot 54$ \\
\hline Group contact* & $0 \cdot 58$ & $0 \cdot 12-2 \cdot 79$ \\
\hline \multicolumn{3}{|l|}{ (c) Hookworm } \\
\hline Origin & $2 \cdot 87$ & $0 \cdot 38-21 \cdot 67$ \\
\hline $\begin{array}{l}\text { Captive status (heterogeneous } \\
v s \text { semi-captive) }\end{array}$ & $2373 \cdot 38$ & $0 \cdot 00-(一)$ \\
\hline $\begin{array}{l}\text { Captive status (captive } v s \\
\text { semi-captive) }\end{array}$ & $0 \cdot 42$ & $0 \cdot 04-4 \cdot 53$ \\
\hline \multicolumn{3}{|l|}{$\begin{array}{l}\text { (d) 'Trichostrongylus-like' } \\
\text { nematodes }\end{array}$} \\
\hline Origin & $(-)$ & $0 \cdot 00-(-)$ \\
\hline Group contact* & 0.00 & $0 \cdot 00-(-)$ \\
\hline Number of individuals $^{\circ}$ & $0 \cdot 00$ & $0 \cdot 00-(-)$ \\
\hline
\end{tabular}

* Group contact $=$ without tactile contact $v s$ with tactile contact.

- Number of individuals $=$ number of individuals per group.

groups in which all individuals, and especially infants, have more tactile contact with each other (Delgado and Van Schaik, 2000). In this study, no significant difference was found between females with or without offspring, indicating that offspring does not increase infection risk in females. Bornean orangutans only form small temporary social units of 2 or 3 individuals (Delgado and Van Schaik, 2000; Harrison, 2009), and females spend much less time in associations than Sumatran females (Van Schaik, 1999; Wich et al. 1999). Infection risk in these units may be lower for a soil-transmitted nematode than in larger groups.

However, from the perspective of disease risk, spatial isolation could be viewed as an adaptive
Table 7. Odds ratios (OR) and $95 \%$ confidence intervals (CI) for the averaged models for individuals at field sites

\begin{tabular}{lll}
\hline \hline Model & OR & $95 \% \mathrm{CI}$ \\
\hline (a) Entamoeba spp. & & \\
Age & $5 \cdot 27$ & $0 \cdot 25-111 \cdot 16$ \\
Flanged & $0 \cdot 24$ & $0 \cdot 01-3 \cdot 95$ \\
(b) Hookworm & & \\
Sex (males $v$ s females) & $\mathbf{4 \cdot 3 8}$ & $\mathbf{1 \cdot 3 7 - 1 4 \cdot 0 6}$ \\
Origin & $0 \cdot 86$ & $0 \cdot 42-1 \cdot 74$ \\
\hline \hline
\end{tabular}

strategy of the primate host to avoid soil-transmitted parasites. Spatial isolation of social groups or individuals is known to be an effective strategy in preventing transmission or attack of pathogens (Loehle, 1995). The different results of Mul et al. (2007) and this study therefore indicate that the level of arboreality and ranging patterns of this ape may be linked to avoidance of faecal-contaminated pathways, as suggested by Freeland (1980) for Mangabeys (Cercocebus albigena). Thus, in addition to the predator hypothesis mentioned above, these results may also represent a link between orangutan socioecology and disease risk, reflecting the consequences of variation in the social structure of these two orangutan species for infection risk from at least one important nematode group.

To our knowledge, this is the first record of Hymenolepis eggs in the faeces from orangutans. Eggs of these cestode species were found in 2 male and 1 female orangutans from the Tuanan site. The eggs were morphologically indistinguishable from eggs of $H$. diminuta which is widely distributed in rats, with arthropods serving as intermediate hosts. No proglottids of Hymenolepis sp. were found in the faeces. Similarly, eggs of a dicrocoeliid were found in 5 orangutans, 4 of which were rescued from oil-palm plantations. The eggs morphologically resembled those of D. dendriticum. The genus Dicrocoelium has been described previously in Bornean orangutans (Collet et al. 1986; Djojosudharmo and Gibson, 1993). Its life cycle includes ants as intermediate hosts and mammals, including humans, as final hosts. In this study, the infected individuals most probably acquired the eggs of both genera through accidental ingestion of infected invertebrate hosts, which are frequently consumed by orangutans in peat swamps (e.g. Harrison, 2009). However, to what extent both parasites may be infectious to orangutans, giving the ape a role in the parasites' life cycle, can neither be inferred from the findings of this nor from previous studies (see Collet et al. 1986; Djojosudharmo and Gibson, 1993).

The ranking of the variables according to the AICc weight sums resulted in 2 significant differences for the re-introduction centres. Whereas age had the 
strongest influence on infection risk for Strongyloides in individuals, the centres themselves significantly influenced the infection risk for Balantidium in captive groups. In individuals, infants $\leqslant 5$ years of age had a significantly higher risk of infection with Strongyloides than orangutans $>8$ years. The reproductive cycle of Strongyloides $\mathrm{sp}$. is almost unique among nematode parasites of vertebrates, in that it includes a free-living adult generation, which mates to produce eggs and progeny (Viney and Lok, 2007). Tropical climate conditions favour sexual reproduction and thereby provide a relatively high number of infective larvae for host invasion. Infected young individuals in captivity easily pass the infection to group members. Prevalence in young individuals is generally typically higher than in adults (Viney and Lok, 2007), with captive infant and juvenile orangutans being particularly susceptible to developing hyperinfection and strongyloidosis (Cummins et al. 1973; Wells et al. 1990). This high susceptibility in comparison to other great apes may have an immunological basis, because arboreal orangutans in the wild have fewer occasions to acquire an infection (Harper et al. 1982). With $42 \%$ of all orangutans kept at the two centres being $\leqslant 5$ years of age, the age composition in the centres resulted in a shift towards a higher percentage of immature individuals compared to natural conditions. Captive situations can afford to keep young individuals in groups and on the ground, meaning that the adaptive strategies of the species to prevent infection cannot come to effect. In contrast, age does not seem to have a significant influence on the prevalence of Strongyloides sp. in wild orangutans (see Foitová et al. 2009). Furthermore, in an internal survey carried out by centre 1 , only 3 of 15 examined caretakers tested negative and the identified parasites were identical to those found in the orangutans. Infant orangutans regularly defecated onto the centre's lawn and other grounds. The caretakers had daily physical contact with about 60 infant orangutans, but did not wear any protective clothing (boots, gloves), allowing intestinal parasites to be transferred back and forth between orangutans and staff. The animals and their environment on one side, and the human caretakers on the other, may therefore represent a relevant source of infection for each other. The potential risk of contact with humans on parasite prevalence in nonhuman primates has also been described by other authors (for an overview see Foitová et al. 2009). Prevalence for Strongyloides sp. was also higher in captive compared to wild orangutans in other studies, although the difference was not significant (see Warren, 2001; Mul et al. 2007). The results of this study clearly indicate an anthropogenic influence on parasite prevalence, bolstered by unnatural husbandry conditions (shift of age composition, dense groups, time spent on the ground), and supports the contention that in communities comprised of closely related species, cross-species interaction may be an important source of infection (Ezenwa, 2003).

The infection risk for Balantidium sp. was significantly higher in centre 1 than centre 2. Balantidium $s p$. is the only facultative pathogenic ciliate. $B$. coli are widely distributed in monkeys in the tropics (Garcia and Bruckner, 1997) which are considered a reservoir for humans. Under humid conditions, $B$. coli cysts can stay infectious for weeks and therefore survive for a long time within a host population. In this study, $16(76 \%)$ of 21 groups at centre 1 tested positive for Balantidium sp., of which 13 also tested positive for Strongyloides sp., hookworms and/or Trichostrongylus-like nematodes. Balantidium sp. may have functioned as a secondary infection, although no correlation with signs of diarrhoea was found. Highest prevalence for Balantidium sp. in the centres was found in groups of $>2$ animals with tactile contact to conspecifics outside of their group and/or access to a neighbouring forest, staying at the centre for $>21$ days, and in groups consisting of mothers with their infants. Captive groups can easily be infected through various sources, including newly-arriving individuals, contaminated food or water, insects, and other primates or animal species in the forest. In combination with the physical contact between the infected groups, which were of young age, this most probably contributed to the result for centre 1 . In addition, this centre took care of 7 semi-captive mothers with their infants, of which 5 tested positive for Balantidium sp. Being rescued from plantations and protecting their offspring while in captivity, these mothers were constantly susceptible to stress and subsequently to infections with this parasite. The synergistic relationship between stress and Balantidium infections has been shown in several studies (Anargyrou et al. 2003; Ho-Seong et al. 2006). A study on red colobus by Chapman et al. (2006) supports the hypothesis that stress weakens the immune system and leads to a higher prevalence of parasite infection. Host density positively correlates with parasite prevalence and diversity (Packer et al. 1999), not only in the field, and host density is positively linked to the spread of directly transmitted parasites (Arneberg, 2002). The unnatural density of the investigated groups and possible rank competition in those with older individuals should have increased the stress level of the group members, thereby increasing their susceptibility to infection.

In the present study, we examined specific parameters that influence infection risk for intestinal parasites in wild and captive orangutans. Our results have relevance for conservation and management plans for Bornean orangutans, as well as Indonesian public health programmes. Further investigations of factors, such as life history, social contact, range-use intensity, diet and habitat diversity on infectious disease dynamics, are needed in order to better 
understand the influence of these factors in reducing or increasing infection risk from intestinal parasites in orangutan populations. Molecular tools should assist in conducting future epidemiological investigations of the parasites.

\section{ACKNOWLEDGEMENTS}

We would like to thank the Indonesian Institute of Science (LIPI) and the Indonesian Nature Conservation Service (PHKA) for permission to work in Indonesia. We thank the Borneo Orangutan Survival Foundation in Indonesia for their support and the permission to work in their reintroduction centres. We also thank the field staff at the Tuanan Research Station, the Natural Laboratory of Peat Swamp Forest, Sabangau, and the Sungai Lading Research Station as well as the staff of BOS' two reintroduction centres Nyaru Menteng and Wanariset for their assistance. We thank the Laboratory of Parasitology, University Gadjah Mada, for offering their facilities. We also acknowledge the Centre for the International Cooperation in Management of Tropical Peatlands for permission to work in Sabangau and are thankful to Helen Morrogh-Bernard and Suwido Limin for their support. This work was supported by a grant from the Messerli Foundation, Switzerland.

\section{REFERENCES}

Akaike, H. (1973). Information theory and an extension of the maximum likelihood principle. In Second International Symposium on Information Theory, Tsahkadsor, Armenian SSR (ed. Petrov, B. N. and Csaki, F.), pp. 267-281. Akademiai Kiado, Budapest, Hungary.

Anargyrou, K., Petrikkos, G. L., Suller, M. T. E., Skiada, A., Siakantaris, M. P., Osuntoyinbo, R. T., Pangalis, G. and Vaiopoulos, G. (2003). Pulmonary Balantidium coli infection in a leukemic patient. American Fournal of Hematology 73, 180-183.

Appelbee, A. J., Thompson, R. C. A. and Olson, M. E. (2005). Giardia and Cryptosporidium in mammalian wildlife - current status and future needs. Trends in Parasitology 21, 370-376.

Arneberg, P. (2002). Host population density and body mass as determinants of species richness in parasite communities: comparative analyses of directly transmitted nematodes of mammals. Ecography 25, $88-94$.

Ashford, R. W., Reid, G. D. F. and Butynski, T. M. (1990). The intestinal faunas of man and mountain gorillas in a shared habitat. Annals of Tropical Medicine and Parasitology 84, 337-340.

Bastian, M. L. (2008). Effects of a riverine dispersal barrier on cultural similarity in wild Bornean orangutans (Pongo pygmaeus wurmbii). Ph.D. dissertation, Duke University, Durham, NC, USA.

Brooks, J. I., Rud, E. W., Pilon, R. G., Smith, J. M., Switzer, W. M. and Sandstrom, P. A. (2002). Cross-species retroviral transmission from macaques to human beings. Lancet 260, 387-388.

Burnham, K. and Anderson, D. (1998). Model Selection and Inference: A Practical Information-theoretic Approach. Springer, New York, USA.
Chapman, C. A., Wasserman, M. D., Gillespie, T. R., Speirs, M. L., Lawes, M. J., Saj, T. L. and Ziegler, T. E. (2006). Do food availability, parasitism, and stress have synergistic effects on red colobus populations living in forest fragments? American Yournal of Physical Anthropology 131, 525-534.

Chen, F. C. and Li, W. H. (2001). Genomic divergences between humans and other hominoids and the effective population size of the common ancestor of humans and chimpanzees. American Fournal of Human Genetics 68, 444-456.

Chitwood, M. (1970). Comparative relationships of some parasites of man and old and new world subhuman primates. Laboratory Animal Care 20, 389-394.

Collet, J. Y., Galdikas, B. M. F., Sugarjito, J. and Jojosudharmo, S. (1986). A coprological study of parasitism in orangutans (Pongo pygmaeus) in Indonesia. Fournal of Medical Primatology 15, 121-129.

Cross, J. H., Clarke, M. D., Cole, W. C., Lien, J. C., Partono, F., Djakaria, Joesoef, A. and Oemijati, S. (1976). Parasitic infections in humans in West Kalimantan (Borneo), Indonesia. Tropical Geographical Medicine 28, 121-130.

Cross, J. H., Clarke, M. D., Durfee, P. T., Irving, G. S., Taylor, J., Partono, F., Joesoef, A., Hudojo and Oemijati, S. (1975). Parasitology survey and seroepidemiology of amoebiasis in South Kalimantan (Borneo), Indonesia. Southeast Asian Fournal of Tropical Medicine and Public Health 6, 52-60.

Cummins, L. B., Keeling, M. E. and McClure, H. M. (1973). Preventative medicine in anthropoids: parasite control. Laboratory Animal Science 23, 819-822.

Current, W. L. (1989). Cryptosporidiosis. In New Strategies in Parasitology (ed. McAdam, K. P. W. J.), pp. 257-273. Livingstone, Edinburgh, UK.

Delgado, R. A. and Van Schaik, C. P. (2000). The behavioural ecology and conservation of the orangutan (Pongo pygmaeus): A tale of two islands. Evolutionary Anthropology 9, 201-218.

Djojosudharmo, S. and Gibson, A. T. (1993). Parasit intestinalis pada primat liar di Taman Nasional Gunung Leuser, Sumatra. In Simposium and Seminar Nasional Primata, Bandung, Sumatra. pp. 13-14.

Eberle, R. and Hilliard, J. K. (1989). Serological evidence for variation in the incidence of herpesvirus infections in different species of apes. Fournal of Clinical Microbiology 27, 1357-1366.

Ezenwa, V. O. (2003). Habitat overlap and gastrointestinal parasitism in sympatric African bovids. Parasitology 126, 379-388.

Foitová, I., Huffman, M. A., Wisnu, N. and Olsansky, M. (2009). Parasites and their impacts on orangutan health. In Orangutans - Geographic Variation in Behavioral Ecology and Conservation (ed. Wich, S. A., Utami Atmoko, S. S., Setia, T. M. and Van Schaik, C. P.), pp. 157-169. Oxford University Press, Oxford, UK.

Freeland, W. J. (1980). Mangabey (Cercocebus albigena) movement patterns in relation to food availability and faecal contamination. Ecology 61, 1297-1303.

Freeman, A. S., Kinsella, J. M., Cipolletta, C., Deem, S. L. and Karesh, W. B. (2004). Endoparasites of Western Lowland Gorillas (Gorilla gorilla gorilla) at Bai 
Hokou, Central African Republic. Fournal of Wildlife Diseases 40, 775-781.

Garber, P. A. (2008). Disease transmission from humans to wild apes: perspectives on the costs and benefits of research and conservation. American Fournal of Primatology 70, 715.

Garcia, L. S. and Bruckner, D. A. (1997). Diagnostic Medical Parasitology, 3rd. edn. ASM Press, Washington, USA.

Graczyk, T. K., Bosco-Nizeyi, J., Ssebide, B., Thompson, R. C., Read, C. and Cranfield, M. R. (2002). Anthropozoonotic Giardia duodenalis genotype (assemblage) infections in habitats of free-ranging human-habituated gorillas, Uganda. Fournal of Parasitolgy 88, 905-909.

Graczyk, T. K., DaSilva, A. J., Cranfield, M. R., Nizeyi, J. B., Kalema, G. R. and Pieniazek, N. J. (2001). Cryptosporidium parvum genotype 2 infections in free-ranging mountain gorillas (Gorilla gorilla beringei) of the Bwindi Impenetrable National Park, Uganda. Parasitology Research 87, 368-370.

Graczyk, T. K., Lowenstine, L. J. and Cranfield, M. R. (1999). Capillaria hepatica (Nematoda) infections in human-habituated mountain gorillas (Gorilla gorilla beringei) of the Parc National de Volcans, Rwanda. Fournal of Parasitology 85, 1168-1170.

Grimm, T. A., Beer, B. E., Hirsch, V. M. and Clouse, K. A. (2003). Simian immunodeficiency viruses from multiple lineages infect human macrophages: implications for cross-species transmission. Fournal of Acquired Immune Deficiency Syndromes 32, 362-369.

Groves, C. P. (1999). The taxonomy of orang-utans. In Orangutan Action Plan (ed. Yeager, C.), pp. 27-30. WWF, Jakarta, Indonesia.

Harper, J., Rice, J. M., London, W. T., Sly, D. L. and Middleton, C. (1982). Disseminated strongyloidosis in Erythrocebus patas. American Fournal of Primatology 3, 89-98.

Harrison, M. E. (2009). Orang-utan feeding behaviour in Sabangau, Central Kalimantan. Ph.D. dissertation, University of Cambridge, Cambridge, UK.

Hira, P. R. and Patel, B. G. (1980). Human strongyloidiasis due to the primate species Strongyloides fülleborni. Tropical and Geographical Medicine 32, 23-29.

Hope, K., Goldsmith, M. L. and Graczyk, T. (2004). Parasitic health of olive baboons in Bwindi Impenetrable National Park, Uganda. Veterinary Parasitology 122, 165-170.

Ho-Seong, C., Sung-Shik, S. and Nam-Yong, P. (2006). Balantidiasis in the gastric lymph nodes of Barbary sheep (Ammotragus lervia): an incidental finding. Fournal of Veterinary Science 7, 207-209.

IUCN (2008). IUCN Red List of Threatened Species. www.redlist.org

Johnson, J. B. and Omland, K. S. (2004). Model selection in ecology and evolution. Trends in Ecology and Evolution 19, 101-108.

Joseph, S. W., Carney, W. P., Van Peenen, P. F., Russell, D. and Saroso, J. S. (1978). Human parasitosis of the Malili area, South Sulawesi (Celebes) province, Indonesia. Southeast Asian Fournal of Tropical Medicine and Public Health 9, 264-271.

Karesh, W. B. and Reed, P. (2004). Population health concerns for lowland gorillas and other great apes.
Diseases - the Third Major Threat for Wild Great Apes? Max Planck Institute for Evolutionary Anthropology, Leipzig, Germany 6-9 May, 2004.

Kaur, T., Singh, J., Tong, S., Humphrey, C., Clevenger, D., Tan, W., Szekely, B., Wang, Y., Li, Y., Muse, E. A., Kiyono, M., Hanamura, S., Inoue, E., Nakamura, M., Huffman, M. A., Jiang, B. and Nishida, T. (2008). Descriptive epidemiology of fatal respiratory outbreaks and detection of a human-related metapneumovirus in wild chimpanzees (Pan troglodytes) at Mahale Mountains National Park, Western Tanzania. American Fournal of Primatology 70, 738-744.

Kilbourn, A. M., Karesh, W. B., Wolfe, N. D., Bosi, E. J., Cook, R. A. and Andau, M. (2003). Health evaluation of free-ranging and semi-captive orangutans (Pongo pygmaeus pygmaeus) in Sabah, Malaysia. Fournal of Wildlife Diseases 39, 73-83.

Knott, C. D. (2001). Female reproductive ecology of the apes: implications for human evolution. In Reproductive Ecology and Human Evolution (ed. Ellison, P. T.), pp. 429-463. Walter de Gruyter, New York, USA.

Knott, C. D. (2005). Energetic responses to food availability in the great apes: Implications for hominin evolution. In Primate Seasonality: Implications for Human Evolution (ed. Brockman, D. and Van Schaik, C. P.), pp. 351-378. Cambridge University Press, Cambridge, UK.

Landsoud-Soukate, J., Tutin, C. E. G. and Fernandez, M. (1995). Intestinal parasites of sympatric gorillas and chimpanzees in the Lopé Reserve, Gabon. Annals of Tropical Medicine and Parasitology 89, 73-79.

Leeflang, P. D. and Markham, R. J. (1986). Strongyloidosis in orang-utans (Pongo pygmaeus) at Perth Zoo: an apparently successful eradication programme. International Zoo Yearbook 24, 256-260. doi: 10.1111/J1748-1090.1985.TB02550-X.

Ley-Vela, M. (2005). Diurnal primate distribution and density in the Sabangau National Park, Central Kalimantan, Indonesia. M.Res. thesis, University of Roehampton, Roehampton, Surrey, UK.

Loehle, C. (1995). Social barriers to pathogen transmission in wild animal populations. Ecology 76, 326-335.

Maggioncalda, A. N., Sapolsky, R. M. and Czekala, N. M. (1999). Reproductive hormone profiles in captive male orangutans: Implications for understanding developmental arrest. American Fournal of Physical Anthropology 109, 19-32.

Marti, H. and Escher, E. (1990). SAF - Eine alternative Fixierlösung für parasitologische Stuhluntersuchungen. Schweizerische Medizinische Wochenschrift 120, 1473-1476.

Michaud, C., Tantalean, M., Ique, C., Montoya, E. and Gozalo, A. (2003). A survey for helminth parasites in feral New World non-human primate populations and its comparison with parasitological data from man in the region. Fournal of Medical Primatology 32, 341-45.

Miyamoto, M. M., Koop, B. F., Slightom, J. L., Goodman, M. and Tennant, M. R. (1988). Molecular systematics of higher primates: Genealogical relations and classification. Proceedings of the National Academy of Sciences, USA 85, 7627-7631. 
Mul, I. F., Paembonan, W., Singleton, I., Wich, S. A. and Van Bolhuis, E. G. (2007). Intestinal parasites of free-ranging, semicaptive, and captive Pongo abelii in Sumatra, Indonesia. International Fournal of Primatology 28, 407-420. doi : 10.1007/S10764-0079119-7.

Muller, R. (2002). Worms and Human Disease, 2nd edn. CABI Publishing, CABI International, Wallingford, UK.

Norusis, M. J. (1986). SPSS/PC+Advanced Statistics, 1 st Edn. SPSS Inc., Chicago.

Nunn, C. L. and Altizer, S. (2006). Infectious Diseases in Primates. Behavior, Ecology and Evolution, 1st. Edn. Oxford University Press, Oxford, UK.

Ott-Joslin, J. E. (1993). Zoonotic diseases of nonhuman primates. In Zoo and Wild Animal Medicine: Current Therapy (ed. Fowler, M. E.), pp. 358-373. W. B. Saunders, Philadelphia, PA, USA.

Packer, C., Altizer, S., Appel, M., Brown, E., Martenson, J., O'Brian, S. J. and Roelke-Parker, M. (1999). Viruses of the Serengeti: patterns of infection and mortality in African lions. Fournal of Animal Ecology 68, 1161-1178.

Pusey, A. E., Wilson, M. L. and Collins, D. A. (2008). Human Impacts, Disease Risk, and Population Dynamics in the Chimpanzees of Gombe National Park, Tanzania. American fournal of Primatology 70, 738-744

Putrali, J., Carney, W. P., Stafford, E. E. and Tubo, S. (1977). Intestinal and blood parasites in the Banggai Kabupaten, Central Sulawesi, Indonesia. Southeast Southeast Asian Fournal of Tropical Medicine and Public Health 8, 375-379.

Rijksen, H. D. (1978). A Field Study on Sumatran Orang Utans (Pongo pygmaeus abelli Lesson 1827) : Ecology, Behaviour and Conservation. Ph.D. dissertation. Veenan, H. \& Zonen B.V., Wageningen, The Netherlands.

Rijksen, H. D. and Meijaard, E. (1999). Our Vanishing Relative: the Status of Wild Orang-Utans at the Close of the Twentieth Century. Kluwer Academic Publishers, Dordrecht, The Netherlands.

Schmidt, U. (1971). Parasitologische Kotuntersuchung durch ein neues Verduennungsverfahren. Tieraerztliche Umschau 26, 229-230.

Setia, T. M., Delgado, R. A., Utami Atmoko, S. S., Singleton, S. and Van Schaik, C. P. (2009). Social organizsation and male-female relationships. In Orangutans - Geographic Variation in Behavioral Ecology and Conservation (ed. Wich, S. A., Utami Atmoko, S. S., Setia, T. M. and Van Schaik, C. P.), pp. 245-253. Oxford University Press, Oxford, UK.

Singleton, I. and Van Schaik, C. P. (2001). Orangutan home range size and its determinants in a Sumatran swamp forest. International Fournal of Primatology 22, 877-911.

Sleeman, J. M., Meader, L. L., Mudakikwa, A. B., Foster, J. W. and Patton, S. (2000). Gastrointestinal parasites of mountain gorillas (Gorilla gorilla beringei) in the Parc National des Volcans, Rwanda. Fournal of Zoo and Wildlife Medicine 31, 322-328.

Utami, S. S., Goossens, B., Bruford, M. W., De Ruiter, J. R. and Van Hooff, A. R. A. M. (2002). Male bimaturism and reproductive success in Sumatran orang-utans. Behavioral Ecology 13, 643-652.
Utami Atmoko, S. S., Singleton, I., Van Noordwijk, M. A., Van Schaik, C. P. and Mitra Setia, T. (2009a). Male-male relationships in orangutans. In Orangutans - Geographic Variation in Behavioral Ecology and Conservation (ed. Wich, S. A., Utami Atmoko, S. S., Setia, T. M. and Van Schaik, C. P.), pp. 225-233. Oxford University Press, Oxford, UK.

Utami Atmoko, S. S., Mitra Setia, T., Goossens, B., James, S. S., Knott, C. D., Morrogh-Bernard, H. C., Van Schaik, C. P. and Van Noordwijk, M. A. (2009b). Orangutan mating behaviour and strategies. In Orangutans - Geographic Variation in Behavioral Ecology and Conservation (ed. Wich, S. A., Utami Atmoko, S. S., Setia, T. M. and Van Schaik, C. P.), pp. 235-244. Oxford University Press, Oxford, UK.

Van Heuverswyn, F., Li, Y., Neel, C., Bailes, E., Keele, B. F., Liu, W., Loul, S., Butel, C., Liegeois, F., Bienvenue, Y., Ngolle, E. M., Sharp, P. M., Shaw, G. M., Delaporte, E., Hahn, B. H. and Peeters, M. (2006). Human immunodeficiency viruses: SIV infection in wild gorillas. Nature, London 444, 164.

Van Schaik, C. P. (1999). The socioecology of fissionfusion sociality in orangutans. Primates 40, 69-86.

Van Schaik, C. P., Wich, S. A., Utami, S. S. and Odom, K. (2005). A simple alternative to line transects of nests for estimating orangutan densities. Primates 46, 249-254.

Viney, M. E. and Lok, J. B. (2007). Strongyloides spp. In The C. elegans Research Community, WormBook (ed. Hodgkin, J. and Anderson, P.), www.wormbook.org. doi/10.1895/wormbook.1.141.

Vitone, N. D., Altizer, S. M. and Nunn, C. L. (2004). Body size, diet and sociality influence the species richness of parasitic worms in anthropoid primates. Evolutionary Ecology Research 6, 1-17.

Warren, K. S. (2001). Orangutan conservation - epidemiological aspects of health management and population genetics. Ph.D. dissertation, Murdoch University, Australia.

Wells, S. K., Sargeant, E., Andrews, M. E. and Anderson, D. E. (1990). Gastrointestinal disorders. In Medical Management of the Orangutan (ed. Wells, S.), pp. 65-66. The Audobon Institute, Louisiana, USA.

Whitfield, J. (2003). Ape populations decimated by hunting and Ebola virus. Nature, London 422, 551.

Wich, S. A., Meijaard, E., Marshall, A. J., Husson, S., Ancrenaz, M., Lacy, R. C., Van Schaik, C. P., Sugardjito, J., Simorangkir, T., Traylor-Holzer, K., Doughty, M., Supriatna, J., Dennis, R., Gumal, M., Knott, C. D. and Singleton, I. (2008). Distribution and conservation status of the orangutan (Pongo spp.) on Borneo and Sumatra: how many remain? Oryx 42, 329-339.

Wich, S. A., Sterck, E. H. M. and Utami, S. S. (1999). Are orangutan females as solitary as chimpanzee females? Folia Primatologia 70, 23-28.

Williams, J. M., Lonsdorf, E. V., Wilson, M. L., Schumacher-Stankey, J., Goodall, J. and Pusey, A. E. (2008). Causes of death in the Kasekela chimpanzees of Gombe National Park, Tanzania. American Fournal of Primatology 70, 738-744.

Xu, X. and Arnason, U. (1996). The mitochondrial DNA molecule of Sumatran orangutan and a 
molecular proposal for two (Bornean and Sumatran) species of orangutan. Fournal of Molecular Evolution 43, 431-437.

Yamagiwa, J. (2004). Diet and foraging of the great apes: ecological constraints on their social organizations and implications for their divergence. In The Evolution of Thought: Evolutionary Origins of Great Ape Intelligence (ed. Russon, A. E. and Begun, D. R.), pp. 210-233. Cambridge University Press, Cambridge, UK. 